\title{
Concentration changeability of phosphorus, calcium and magnesium in selected partial drainage basins of the River Drwęca
}

\author{
Bożena Pius \\ Department of Hydrology and Water Management, Faculty of Earth Sciences NCU in Toruń, Lwowska 1, 87-100 Toruń, e-mail: \\ bpius@umk.pl
}

\begin{abstract}
The paper presents the results of the research conducted between November 2008 and October 2009. The research included seasonal dynamics of the flow and runoff of phosphorus compounds ( $\mathrm{TP}$ and $\mathrm{P}_{-} \mathrm{PO}_{4}^{3-}$ ), as well as $\mathrm{Ca}^{2+}$ and $\mathrm{Mg}^{2+}$ from 13 partial drainage basins of the River Drwęca. Water levels were registered automatically every day by recorders, and measurements of the flow were conducted once a month. Major differences were found in the water abundance as indicated by specific discharges in individual, partial drainage basins: from $1.87 \mathrm{dm}^{3} \mathrm{~s}^{-1} \mathrm{~km}^{-2}$ (Lubianka - a lower part of the River Drwęca drainage basin) to $8.22 \mathrm{dm}^{3} \mathrm{~s}^{-1} \mathrm{~km}^{-2}$ (Gizela - an upper part of the River Drwęca drainage basin). The studied rivers were characterised by very diverse average content of total phosphorus compounds: from $0.047 \mathrm{mg} \mathrm{dm}^{-3}$ (Iłga) to $0.816 \mathrm{mg} \mathrm{dm}^{-3}$ (Sandela); calcium: from $47.18 \mathrm{mg} \mathrm{dm}^{-3}$ (Iłga) to 131.65 $\mathrm{mg} \mathrm{dm}{ }^{-3}$ (Trynka); and magnesium: from $9.71 \mathrm{mg} \mathrm{dm}^{-3}$ (Wel) to $36.76 \mathrm{mg} \mathrm{dm}^{-3}$ (Struga Rychnowska). Analysis of variance carried out on hydrochemical properties of the studied rivers divides the rivers into two separate groups: rivers with much higher content of phosphorus, calcium and magnesium compounds (Struga Rychnowska, Trynka, Ruziec, Lubianka, Kujawka, Sandela and Gizela), and a group of rivers with low content of these compounds (Brynica, Brodniczanka, Skarlanka, Wel, Iłga).
\end{abstract}

Key words: River Drwęca drainage basin, runoff rate, phosphorus, calcium, magnesium

\section{Introduction}

Protection of surface waters is one of the main priorities of the European environmental policy. In the European Union, the Directive 2000/60/EC has been in force since 2000 - the Water Framework Directive (WFD), the objective of which is to provide effective protection of surface and groundwater (EC 2000). WFD introduces an ecological, holistic approach to the evaluation of the water level and planned water management in river drainage basins in accordance with the principles of sustainable development. WFD guidelines are ambitious: achieving a "good ecological status" by 2015. In this context, the Directive is of great importance for the reduction of surface water eutrophication (Neal and Jarvie 2005), which is limited by the phosphorus content in river waters (Mainstone and Parr 2002; Withers and Jarvie 2009).

There is no doubt that agriculture is the key factor of surface water contamination in Poland (Jasiewicz and Baran 2006; Banaszuk 2007). This is connected with mineral and organic fertilisation, as well as animal husbandry (Koc and Szymczyk 2003). Nonpoint source pollution is brought into the rivers via surface runoff, which is thought to be the most important factor in the catchment phosphorus translocation (Pionke et al. 1999; Sharpley et al. 1999). The amount of phosphorus reaching the watercourses is determined by many factors, but hydrological conditions of a given drainage basin are undoubtedly the most important one. The analysis of the course and the rate of fluvial transportation of dissolved compounds (in particular abiotic/mineral) are good determinants of catchment processes. Based on the chemical composition of water, we can identify the mechanisms of the movement of matter from the drainage area, determine its sources, feeding areas and migration routes of dissolved elements (Soulsby et al. 2000). Soil phosphorus is characterised by negligible mobility; therefore the main role in the transport of phosphorus is played by processes occurring on the soil surface. This water erosion is the key process responsible for phosphorus runoff from the catchment (Walling 2005; Laborious 2006). Phosphorus can be washed out 
from agricultural catchments, both in a dissolved or elemental form (Grant et al. 1996; Haygarth and Jarvis 1999; Heathwaite and Dils 2000); however, phosphorus adsorbed on soil particles definitely dominates. And thus, the phosphorus runoff from agricultural lands is a function of the availability of phosphorus in the form that can be eluted and of the mechanisms of transportation into the surface waters (McDowell et al. 2001, 2004).

The literature reports on hydrological conditions of phosphorus transport in rivers are both comprehensive (Behrendt and Opitz 1999; Bogdanowicz 2004) and ambiguous. We know for sure that the variability in the concentrations of phosphorus transported in various forms with river waters is characterised by a relationship between the level (expressed both in the concentration and the load) of this chemical element and the river flow rate. This relationship, however, has a different course in different study objects, and the relations can be both increasing and decreasing, i.e. the concentrations increase or decrease together with the flow rate increase. A complete lack of any statistically significant correlation has also been observed. Many studies point to strong seasonality in the runoff of phosphorus compounds from agricultural lands. The largest amounts of this biogenic element are washed out during thaw seasons and during heavy precipitation (Heathwaite and Dils 2000; Mainstone and Parr 2002).

The River Drwęca drainage basin, despite its undeniable natural value, surprisingly seldom constitutes an object of any hydrological or hydrochemical research in general, or comprehensive, dedicated research in particular (Kowalkowski 2009; GlińskaLewczuk and Burandt 2011; Harnisz et al. 2011).

The research aimed to analyse the temporal and spatial hydrological characteristics in the drainage basin of the River Drwęca, as well as analysing the seasonal variability in the concentrations of biogenic elements ( $\mathrm{P}-\mathrm{PO}_{4}^{3-}$, total phosphorus) and biologically inactive compounds (calcium and magnesium) in the conditions of highly diverse runoff rates in different drainage basins.

\section{Study area and Methods}

The River Drwęca, a right-bank tributary of the River Vistula, is a watercourse of the 2 nd order, with a length of $213.73 \mathrm{~km}$. The River Drwęca drainage ba$\sin$ is $5697.4 \mathrm{~km}^{2}$ in area, and is characterised by very heterogeneous hypsometric conditions - the lowest point is located at the confluence of the River Drwęca with the River Vistula ca. $36 \mathrm{~m}$ asl, the highest at Góra Dylewska (Mt.) $312 \mathrm{~m}$ asl. Moraine uplands are the most extensive land relief forms. They are diversified with hummocks and moraine hills, locally with embankments of eskers, kames and deep subglacial troughs. The largest outwash areas are in the Brodnica and Iława Lakelands. Over the area of moraine uplands, diverse loamy deposits occur, on the basis of which very fertile brown or lessive soils developed. In the outwash areas, arenosol and podzol soils occur; they are not fertile and usually overgrown with forests. Tributaries of the River Drwęca are quite symmetrically distributed on both sides of the river (Fig. $1)$.

Preliminary hydrological and hydrochemical studies in the drainage basin of the River Drwęca were conducted between November 2008 and October 2009. The analysis was performed on 13 tributaries of the River Drwęca: Struga Rychnowska, Trynka, Lubianka, Ruziec, Struga Wąbrzeska, Kujawka, Struga Brodnicka, Skarlanka, Brynica, Wel, Sandela, Gizela and Iłga (Table 1, Fig. 1).

Electrolytic conductivity and $\mathrm{pH}$ were measured in the field. In the laboratory, the content of phosphate phosphorus ( $\left.\mathrm{P}_{-} \mathrm{PO}_{4}{ }^{3-}\right)$ and total phosphorus (TP) were determined within less than 24 hours applying the spectrometric method with a molybdate-sulphuric reagent and ascorbic acid as a reducing agent, after prior mineralisation with perchloric and sulphuric acid. The content of calcium $\left(\mathrm{Ca}^{2+}\right)$ and magnesium $\left(\mathrm{Mg}^{2+}\right)$ ions were determined by the method of complexometrictitration with EDTA.

In the studied drainage basins, automatic waterlevel gauges were installed, which registered the water level every 4 hours. The water level recorder is intended for automatic measurements of the water column height in a river bed. Devices were made in-house and their operation principle is based on the phenomenon of capacitor's capacitance. The research on the river flow was conducted with the use of a hydrometric current meter HEGA-2. Knowing the water level in a river and the flow rate attributed to a given water level, one can determine the relationship $Q=f(H)$. On this basis, flow rate curves were plotted, which were used for conversion of water levels into corresponding runoff rates. Flow curves were plotted from data obtained from November 2007 to October 2010 (field tests were performed every two months). Spatial vari- 
Fig. 1. Drainage network of the River Drwęca basin. 1 - Struga Rychnowska, 2 - Trynka, 3 - Lubianka, 4 - Ruziec, 5 - Struga Wąbrzeska, 6 - Kujawka, 7 - Struga Brodnicka, 8 - Skarlanka, 9 Brynica, 10 - Wel, 11 - Sandela, 12 - Gizela, 13 - Iłga

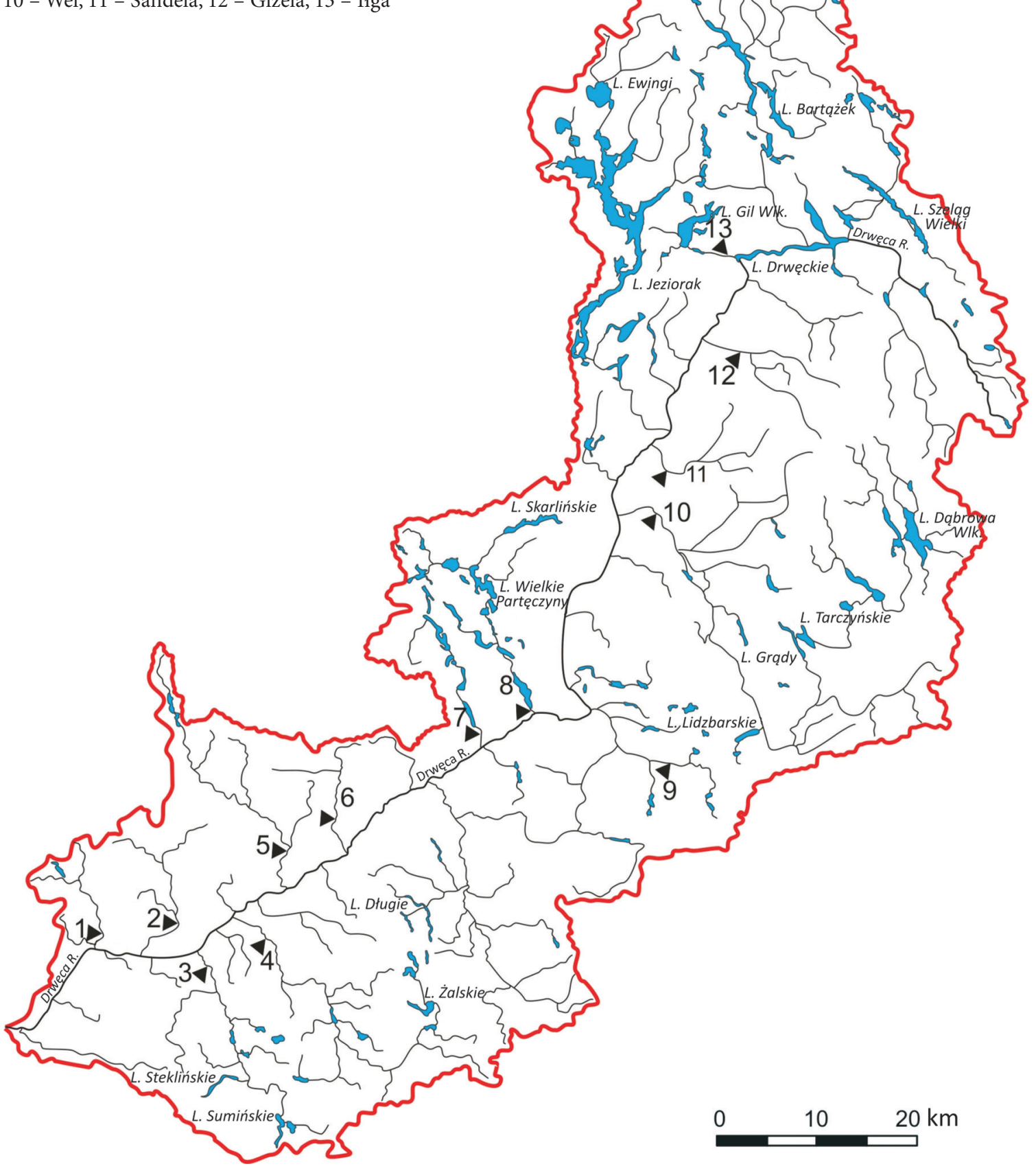

ability in the runoff was described by means of the specific discharge, $q\left(\mathrm{dm}^{3} \mathrm{~s}^{-1} \mathrm{~km}^{-2}\right)$, as it is reflected in values independent of the drainage area size. It enables the comparison of different areas in relation to the water abundance of the studied drainage basin.
In order to investigate the differences in the runoff of phosphorus, calcium and magnesium, depending on the land use of catchments, analysis of variation was performed (one-way ANOVA, the grouping factor was forest cover catchment). 
Table 1. Land use structure and selected physical and geographical parameters and individual runoff events in the studied drainage basins

\begin{tabular}{|c|c|c|c|c|c|c|c|}
\hline River & Catchment area & River length & Forest & Arable land & Wetland & Urban area & Specific discharge \\
\hline & {$\left[\mathrm{km}^{2}\right]$} & {$[\mathrm{km}]$} & [\%] & [\%] & [\%] & [\%] & {$\left[\mathrm{dm}^{3} \mathrm{~s}^{-1} \mathrm{~km}^{2}\right]$} \\
\hline 1 & 48.35 & 14.29 & 19.11 & 77.89 & 0 & 3.00 & 3.16 \\
\hline 2 & 83.01 & 19.33 & 4.81 & 93.12 & 0.71 & 1.36 & 3.32 \\
\hline 3 & 213.91 & 33.72 & 2.17 & 94.42 & 3.11 & 0.28 & 1.87 \\
\hline 4 & 247.8 & 44.46 & 10.79 & 86.04 & 2.98 & 0.17 & 3.04 \\
\hline 5 & 167.99 & 34.69 & 14.94 & 83.09 & 0.63 & 1.32 & 2.48 \\
\hline 6 & 51.62 & 17.73 & 18.79 & 81.2 & 0 & 0 & 3.35 \\
\hline 7 & 90.02 & 15.98 & 28.3 & 63.75 & 6.24 & 1.66 & 3.44 \\
\hline 8 & 231.22 & 26.22 & 37.44 & 54.71 & 7.67 & 0.17 & 3.44 \\
\hline 9 & 78.65 & 22.78 & 85.9 & 12.57 & 2.42 & 0 & 6.81 \\
\hline 10 & 799.1 & 95.8 & 20.15 & 67.85 & 6.75 & 5.25 & 5.03 \\
\hline 11 & 70.04 & 17.88 & 4.49 & 92.68 & 0 & 2.81 & 5.38 \\
\hline 12 & 70.22 & 19.58 & 15.72 & 83.82 & 0 & 0.47 & 8.22 \\
\hline 13 & 58.25 & 5.08 & 65.49 & 23.42 & 11.07 & 0 & 6.99 \\
\hline
\end{tabular}

The numbering of the catchments as shown in Figure 1

\section{Results and Discussion}

\section{Phosphorus}

In the winter season, the percentage content of elemental phosphorus in the total phosphorus ranged from 40 to $60 \%$ (catchment areas dominated by forests), and from 60 to $87 \%$ (catchment areas dominated by agricultural areas), whereas in the summer season, this content was $60-71 \%$ (forest catchment areas) and 38.5-86\% (agricultural catchment areas) respectively.

In respect of the content of phosphorus compounds (both total and phosphate phosphorus), the studied rivers quite clearly can be divided into two groups (Fig. 2). The first group comprises rivers with a predominance of agricultural areas in their drainage basin (the Struga Rychnowska, Trynka, Ruziec, Lubianka, Kujawka, Sandela and Gizela). The average concentration of total phosphorus for individual rivers in this group ranged from 0.16 to $0.82 \mathrm{mg} \mathrm{dm}^{-3}$. The average concentration of total phosphorus in the group of rivers with drainage basins dominated by forests (Brynica, Brodniczanka, Skarlanka, Wel, Iłga) ranged from 0.05 to $0.016 \mathrm{mg} \mathrm{dm}^{-3}$. There were also disproportions in the content of $\mathrm{P}_{-} \mathrm{PO}_{4}^{3-}$, although they were not as pronounced.

No statistically significant correlation was found between the flow rate and the concentration of total and phosphate phosphorus. This implies that the phosphorus runoff from the studied catchment areas is not determined by hydrological factors expressed by the value of the runoff rate. During the studied period, the rate ranged from ca. $2 \mathrm{dm}^{3} \mathrm{~s}^{-1} \mathrm{~km}^{-2}$ in the drainage basin of the Lubianka to ca. $8 \mathrm{dm}^{3} \mathrm{~s}^{-1} \mathrm{~km}^{-2}$ in the drainage basin of the River Gizela (Table 1). Spatial distribution of precipitation within the catchment area of the River Drwęca clearly increases towards NE, which is reflected in the runoff rates. The area with the lowest precipitation extends towards the lower part of the River Drwęca drainage basin (precipitation at Torun was $497 \mathrm{~mm}$ during the study period), whereas the upper part of the drainage basin is characterised by noticeably higher precipitation (Olsztyn $613 \mathrm{~mm}$ ). The contribution of summer precipitation in relation to annual precipitation was $76 \%$ in Torun and $65 \%$ in Olsztyn (Table 2).

In the studied rivers, the largest runoff occurred in March as a result of spring freshets, but due to summer heavy rainfall, no significant reduction in the runoff was observed in the drainage basins in the summer half year. In the winter half year, $46.9 \%$ of the waters ran off, whereas in the summer half year, $53.1 \%$. Our results on the seasonal dynamics in the concentrations and loads of phosphorus compounds are not explicit. When comparing the average concentrations for particular rivers during and after the growing season (Table 3), it is difficult to detect any explicit patterns and differences between agricultural and forest catchment areas. 
Table 3. Hydrochemical characteristics (mean values and the range) of waters in studied rivers

\begin{tabular}{|c|c|c|c|c|c|c|c|c|c|c|c|c|}
\hline \multirow{3}{*}{ 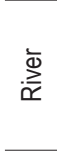 } & \multirow{2}{*}{\multicolumn{2}{|c|}{$\mathrm{pH}$}} & \multirow{2}{*}{\multicolumn{2}{|c|}{$\frac{E C}{\left[\mu \mathrm{S} \mathrm{cm}^{-1}\right]}$}} & \multicolumn{2}{|c|}{ TP } & \multicolumn{2}{|c|}{$\mathrm{P}-\mathrm{PO}_{4}{ }^{3-}$} & \multicolumn{2}{|c|}{$\mathrm{Ca}^{2+}$} & \multicolumn{2}{|c|}{$\mathrm{Mg}^{2+}$} \\
\hline & & & & & {$[\mathrm{mg}$} & & [mg & $\left.\mathrm{Im}^{-3}\right]$ & {$[\mathrm{mg} \mathrm{c}$} & $\left.\mathrm{Im}^{-3}\right]$ & [mg & $\left.\mathrm{dm}^{-3}\right]$ \\
\hline & W & $S$ & W & $S$ & W & $S$ & W & $S$ & W & $S$ & W & $S$ \\
\hline 1 & $\begin{array}{c}8.0 \\
7.8-8.2\end{array}$ & $\begin{array}{c}7.9 \\
7.5-8.1\end{array}$ & $\begin{array}{c}762 \\
727-805\end{array}$ & $\begin{array}{c}707 \\
677-720\end{array}$ & $\begin{array}{c}0.235 \\
0.18-0.34\end{array}$ & $\begin{array}{c}0.288 \\
0.12-0.46\end{array}$ & $\begin{array}{c}0.044 \\
0.03-0.05\end{array}$ & $\begin{array}{c}0.061 \\
0.04-0.07\end{array}$ & $\begin{array}{c}130.7 \\
113.1-146.7\end{array}$ & $\begin{array}{c}123.4 \\
108.2-145.5\end{array}$ & $\begin{array}{c}45.89 \\
36.08-64.12\end{array}$ & $\begin{array}{c}27.65 \\
21.64-32.45\end{array}$ \\
\hline ? & $\begin{array}{c}8.1 \\
7.8-8.3\end{array}$ & $\begin{array}{c}7.9 \\
7.5-8.3\end{array}$ & $\begin{array}{c}775 \\
740-801\end{array}$ & $\begin{array}{c}727 \\
683-771\end{array}$ & $\begin{array}{c}0.234 \\
0.14-0.42\end{array}$ & $\begin{array}{c}0.183 \\
0.07-0.33\end{array}$ & $\begin{array}{c}0.036 \\
0.02-0.03\end{array}$ & $\begin{array}{c}0.052 \\
0.03-0.07\end{array}$ & $\begin{array}{c}129.4 \\
119.4-136.3\end{array}$ & $\begin{array}{c}133.9 \\
119.4-173.9\end{array}$ & $\begin{array}{c}28.06 \\
10.02-36.07\end{array}$ & $\begin{array}{c}22.35 \\
7.23-31.26\end{array}$ \\
\hline 2 & $\begin{array}{c}8.1 \\
7.7-8.5\end{array}$ & $\begin{array}{c}7.9 \\
7.6-8.1\end{array}$ & $\begin{array}{c}620 \\
560-713\end{array}$ & $\begin{array}{c}554 \\
540-568\end{array}$ & $\begin{array}{c}0.183 \\
0.11-0.36\end{array}$ & $\begin{array}{c}0.264 \\
0.19-0.36\end{array}$ & $\begin{array}{c}0.034 \\
0.01-0.05\end{array}$ & $\begin{array}{c}0.162 \\
0.04-0.26\end{array}$ & $\begin{array}{c}97.00 \\
91.0-107.0\end{array}$ & $\begin{array}{c}89.78 \\
75.35-120.2\end{array}$ & $\begin{array}{c}30.25 \\
20.44-46.48\end{array}$ & $\begin{array}{c}30.76 \\
20.04-39.28\end{array}$ \\
\hline 4 & $\begin{array}{c}7.9 \\
7.6-8.3\end{array}$ & $\begin{array}{c}8.0 \\
7.8-8.3\end{array}$ & $\begin{array}{c}602 \\
590-622\end{array}$ & $\begin{array}{c}570 \\
523-608\end{array}$ & $\begin{array}{c}0.206 \\
0.08-0.44\end{array}$ & & $\begin{array}{c}0.035 \\
0.01-0.07\end{array}$ & & $\begin{array}{c}99.61 \\
93.0-109.8\end{array}$ & $\begin{array}{c}94.99 \\
79.35-125.2\end{array}$ & $\begin{array}{c}27.55 \\
25.64-30.46\end{array}$ & $\begin{array}{c}27.76 \\
24.85-32.06\end{array}$ \\
\hline 5 & $\begin{array}{c}7.8 \\
7.5-8.1\end{array}$ & $\begin{array}{c}7.7 \\
7.3-8.0\end{array}$ & $\begin{array}{c}714 \\
705-732\end{array}$ & & & & $\begin{array}{c}0.063 \\
0.00-0.09\end{array}$ & & $\begin{array}{c}116.3 \\
110.2-123.4\end{array}$ & $\begin{array}{c}115.1 \\
96.12-139.1\end{array}$ & $\begin{array}{c}22.15 \\
18.83-24.08\end{array}$ & $\begin{array}{c}35.07 \\
22.84-50.05\end{array}$ \\
\hline 6 & $\begin{array}{c}8.0 \\
7.8-8.2\end{array}$ & $\begin{array}{c}7.8 \\
7.7-7.9\end{array}$ & $\begin{array}{c}596 \\
565-632\end{array}$ & $\begin{array}{c}585 \\
550-636\end{array}$ & & $\begin{array}{c}0.163 \\
0.10-0.25\end{array}$ & $\begin{array}{c}0.043 \\
0.03-0.06\end{array}$ & $\begin{array}{c}0.034 \\
0.02-0.04\end{array}$ & $\begin{array}{c}106.8 \\
91.38-114.6\end{array}$ & $\begin{array}{c}108.9 \\
95.39-118.2\end{array}$ & $\begin{array}{c}16.54 \\
10.45-20.83\end{array}$ & $\begin{array}{c}23.05 \\
6.01-42.09\end{array}$ \\
\hline 7 & $\begin{array}{c}8.0 \\
7.7-8.3\end{array}$ & $\begin{array}{c}8.2 \\
7.8-8.5\end{array}$ & $\begin{array}{c}436 \\
404-478\end{array}$ & $\begin{array}{c}396 \\
370-415\end{array}$ & $\begin{array}{c}0.155 \\
0.09-0.22\end{array}$ & $\begin{array}{c}0.114 \\
0.06-0.14\end{array}$ & $\begin{array}{c}0.094 \\
0.06-0.12\end{array}$ & $\begin{array}{c}0.043 \\
0.01-0.08\end{array}$ & $\begin{array}{c}68.73 \\
64.90-72.14\end{array}$ & $\begin{array}{c}58.91 \\
52.92-67.33\end{array}$ & $\begin{array}{c}22.05 \\
17.64-28.87\end{array}$ & $\begin{array}{c}28.86 \\
23.65-34.07\end{array}$ \\
\hline 8 & $\begin{array}{c}8.2 \\
7.7-8.6\end{array}$ & $\begin{array}{c}8.0 \\
7.8-8.3\end{array}$ & $\begin{array}{c}372 \\
347-412\end{array}$ & $\begin{array}{c}350 \\
336-363\end{array}$ & $\begin{array}{c}0.087 \\
0.06-0.12\end{array}$ & $\begin{array}{c}0.074 \\
0.05-0.08\end{array}$ & $\begin{array}{c}0.042 \\
0.01-0.09\end{array}$ & $\begin{array}{c}0.021 \\
0.00-0.04\end{array}$ & $\begin{array}{c}53.40 \\
48.90-59.31\end{array}$ & $\begin{array}{c}53.60 \\
50.92-56.91\end{array}$ & $\begin{array}{c}20.44 \\
18.44-24.44\end{array}$ & $\begin{array}{c}20.24 \\
16.03-24.05\end{array}$ \\
\hline 9 & $\begin{array}{c}8.1 \\
7.8-8.4\end{array}$ & $\begin{array}{c}8.1 \\
7.8-8.3\end{array}$ & $\begin{array}{c}396 \\
386-403\end{array}$ & $\begin{array}{c}375 \\
365-392\end{array}$ & $\begin{array}{c}0.153 \\
0.12-0.17\end{array}$ & $\begin{array}{c}0.186 \\
0.16-0.21\end{array}$ & $\begin{array}{c}0.061 \\
0.04-0.09\end{array}$ & $\begin{array}{c}0.072 \\
0.06-0.08\end{array}$ & $\begin{array}{c}67.12 \\
64.92-71.69\end{array}$ & $\begin{array}{c}70.74 \\
64.92-79.35\end{array}$ & $\begin{array}{c}14.97 \\
10.87-16.54\end{array}$ & $\begin{array}{c}15.34 \\
8.02-23.05\end{array}$ \\
\hline 10 & $\begin{array}{c}8.3 \\
8.1-8.4\end{array}$ & $\begin{array}{c}7.7 \\
7.4-8.1\end{array}$ & $\begin{array}{c}421 \\
406-430\end{array}$ & $\begin{array}{c}382 \\
362-401\end{array}$ & $\begin{array}{c}0.102 \\
0.08-0.13\end{array}$ & $\begin{array}{c}0.157 \\
0.14-0.16\end{array}$ & $\begin{array}{c}0.042 \\
0.03-0.06\end{array}$ & $\begin{array}{c}0.073 \\
0.05-0.09\end{array}$ & $\begin{array}{c}66.40 \\
64.90-68.10\end{array}$ & $\begin{array}{c}64.23 \\
59.72-70.36\end{array}$ & $\begin{array}{c}10.78 \\
8.25-12.64\end{array}$ & $\begin{array}{c}8.65 \\
7.45-9.97\end{array}$ \\
\hline 11 & $\begin{array}{c}8.0 \\
7.9-8.2\end{array}$ & $\begin{array}{c}7.8 \\
7.7-8.0\end{array}$ & $\begin{array}{c}590 \\
576-602\end{array}$ & $\begin{array}{c}678 \\
568-787\end{array}$ & $\begin{array}{c}0.458 \\
0.28-0.88\end{array}$ & $\begin{array}{c}1.188 \\
0.78-2.16\end{array}$ & $\begin{array}{c}0.101 \\
0.07-0.11\end{array}$ & $\begin{array}{c}0.424 \\
0.17-0.57\end{array}$ & $\begin{array}{c}102.1 \\
90.46-110.2\end{array}$ & $\begin{array}{c}103.3 \\
94.18-118.2\end{array}$ & $\begin{array}{c}21.77 \\
11.75-30.46\end{array}$ & $\begin{array}{c}24.41 \\
16.44-30.86\end{array}$ \\
\hline 12 & $\begin{array}{c}8.3 \\
7.9-8.6\end{array}$ & $\begin{array}{c}8.0 \\
7.8-8.5\end{array}$ & $\begin{array}{c}510 \\
497-517\end{array}$ & $\begin{array}{c}504 \\
484-523\end{array}$ & $\begin{array}{c}0.195 \\
0.15-0.26\end{array}$ & $\begin{array}{c}0.188 \\
0.14-0.20\end{array}$ & $\begin{array}{c}0.072 \\
0.06-0.08\end{array}$ & $\begin{array}{c}0.084 \\
0.04-0.12\end{array}$ & $\begin{array}{c}91.51 \\
88.67-97.20\end{array}$ & $\begin{array}{c}94.99 \\
83.36-115.4\end{array}$ & $\begin{array}{c}23.42 \\
17.64-28.85\end{array}$ & $\begin{array}{c}23.01 \\
15.08-33.27\end{array}$ \\
\hline 13 & $\begin{array}{c}8.3 \\
8.0-8.7\end{array}$ & $\begin{array}{c}8.1 \\
7.8-8.4\end{array}$ & $\begin{array}{c}294 \\
268-344\end{array}$ & $\begin{array}{c}253 \\
237-270\end{array}$ & $\begin{array}{c}0.044 \\
0.03-0.05\end{array}$ & $\begin{array}{c}0.051 \\
0.04-0.09\end{array}$ & $\begin{array}{c}0.021 \\
0.01-0.03\end{array}$ & $\begin{array}{c}0.022 \\
0.02-0.04\end{array}$ & $\begin{array}{c}49.60 \\
43.28-53.30\end{array}$ & $\begin{array}{c}44.78 \\
33.26-58.91\end{array}$ & $\begin{array}{c}15.79 \\
7.84-28.86\end{array}$ & $\begin{array}{c}14.03 \\
5.21-24.85\end{array}$ \\
\hline
\end{tabular}

W - Winter, S - Summer, EC - Electrolytic conductivity, TP - Total phosphorus. The numbering of the river catchments as shown in Figure 1

Table 2. Average monthly flow $\left[\mathrm{m}^{3} \mathrm{~s}^{-1}\right]$ of the studied rivers in the River Drwęca basin

\begin{tabular}{|c|c|c|c|c|c|c|c|c|c|c|c|c|c|}
\hline Month & $\begin{array}{c}\text { Struga } \\
\text { Rychnowska }\end{array}$ & Trynka & Lubianka & Ruziec & $\begin{array}{c}\text { Struga } \\
\text { Wąbrzeska }\end{array}$ & Kujawka & $\begin{array}{l}\text { Struga } \\
\text { Brodnicka }\end{array}$ & Skarlanka & Brynica & Wel & Sandela & Gizela & Ilga \\
\hline$X I$ & 0.145 & 0.282 & 0.344 & 0.550 & 0.519 & 0.177 & 0.211 & 0.542 & 0.594 & 4.920 & 0.289 & 0.499 & 0.267 \\
\hline XII & 0.133 & 0.179 & 0.340 & 0.600 & 0.363 & 0.099 & 0.165 & 0.424 & 0.490 & 4.710 & 0.232 & 0.439 & 0.307 \\
\hline I & 0.100 & 0.120 & 0.380 & 0.790 & 0.183 & 0.090 & 0.280 & 0.719 & 0.510 & 4.710 & 0.238 & 0.435 & 0.379 \\
\hline II & 0.169 & 0.160 & 0.410 & 0.715 & 0.360 & 0.090 & 0.175 & 0.449 & 0.585 & 4.240 & 0.280 & 0.490 & 0.399 \\
\hline III & 0.364 & 0.412 & 0.596 & 1.455 & 0.763 & 0.330 & 0.263 & 0.676 & 0.628 & 5.570 & 0.427 & 0.667 & 0.468 \\
\hline IV & 0.265 & 0.278 & 0.455 & 1.005 & 0.477 & 0.226 & 0.271 & 0.696 & 0.456 & 5.000 & 0.320 & 0.409 & 0.614 \\
\hline V & 0.110 & 0.119 & 0.239 & 0.600 & 0.320 & 0.162 & 0.083 & 0.213 & 0.380 & 3.410 & 0.356 & 0.560 & 0.517 \\
\hline VI & 0.115 & 0.254 & 0.400 & 0.810 & 0.416 & 0.193 & 0.213 & 0.547 & 0.520 & 3.710 & 0.481 & 0.712 & 0.440 \\
\hline VII & 0.155 & 0.476 & 0.566 & 1.130 & 0.747 & 0.190 & 0.351 & 0.902 & 0.520 & 3.550 & 0.432 & 0.614 & 0.478 \\
\hline VIII & 0.090 & 0.433 & 0.375 & 0.630 & 0.309 & 0.147 & 0.391 & 1.004 & 0.494 & 2.780 & 0.352 & 0.584 & 0.417 \\
\hline IX & 0.099 & 0.233 & 0.239 & 0.260 & 0.301 & 0.150 & 0.577 & 1.482 & 0.480 & 2.460 & 0.406 & 0.600 & 0.300 \\
\hline$x$ & 0.090 & 0.362 & 0.446 & 0.485 & 0.441 & 0.220 & 0.735 & 1.888 & 0.770 & 3.210 & 0.709 & 0.915 & 0.297 \\
\hline $\begin{array}{l}\text { runoff in } \\
\text { winter [\%] }\end{array}$ & 36 & 57 & 47 & 43 & 49 & 51 & 63 & 63 & 49 & 60 & 61 & 58 & 50 \\
\hline $\begin{array}{l}\text { runoff in } \\
\text { summer } \\
\text { [\%] }\end{array}$ & 64 & 43 & 53 & 57 & 51 & 49 & 37 & 37 & 51 & 40 & 39 & 42 & 50 \\
\hline
\end{tabular}




\section{Calcium and magnesium}

As in the case of phosphorus compounds, the analysis of $\mathrm{Ca}^{2+}$ and $\mathrm{Mg}^{2+}$ concentrations relatively explicitly differentiates the studied drainage basins into those with the predominance of agricultural lands and those dominated by forests. Average concentrations of calcium in rivers with an agricultural catchment area fluctuated from 93.25 to $131.66 \mathrm{mg} \mathrm{dm}^{-3}$, whereas in river catchments covered with forest, from 47.19 to $68.93 \mathrm{mg} \mathrm{dm}^{-3}$. These results confirm the reports of other authors about more intensive eluviation of calcium ions from agricultural areas compared with forest areas (Koc and Duda 2009). In the case of the magnesium ion, the situation is similar: average concentrations in rivers with an agricultural catchment area ranged from 19.79 to $36.77 \mathrm{mg} \mathrm{dm}^{-3}$, and in rivers with a forest catchment area they ranged from 9.71 to $25.47 \mathrm{mg} \mathrm{dm}^{-3}$. In the context of other studies conducted in surface waters of young post-glacial areas (Koc et al. 2008), such a concentration of $\mathrm{Mg}^{2+}$ ion is relatively high and comparable with concentrations recorded in leachates (Pulikowski et al. 2006).

No significant, seasonal differences in the concentrations of calcium and magnesium were confirmed with statistical methods. No significant correlation was found either between the flow rate and the concentration of calcium and magnesium. The content of $\mathrm{Ca}^{2+}$ and $\mathrm{Mg}^{2+}$ is strongly correlated with electrolytic conductivity $(\mathrm{r}=0.92$ and $\mathrm{r}=52 ; \mathrm{p}<0.05$, respectively). The average value of electrolytic conductivity in the agricultural catchment areas ranged from 507 to $750 \mu \mathrm{S} \mathrm{cm}^{-1}$, and in the forest catchment areas from 273 to $416 \mu \mathrm{S} \mathrm{cm}^{-1}$. High content of calcium and magnesium, as well as high electrolytic conductivity in rivers with drainage basins devoid of forests are evidence of intensive denudation processes.

The ANOVA showed important differences in almost every physical and chemical parameter of river waters according to catchment management (Tables 4 and 5). To examine the differences between the aver-
Table 4. One-way ANOVA for hydrochemical indicators, depending on the land use of the catchment (the grouping factor - forestation of catchment)

\begin{tabular}{lcc}
\hline \multicolumn{1}{c}{ Parameter } & F statistic & P value \\
\hline Total phosphorus - TP & 9.75 & 0.000 \\
Orthophosphate - P-PO ${ }_{4}$ & 7.67 & 0.001 \\
Electrolytic Conductivity - EC & 117.40 & 0.000 \\
Water reaction - pH & 3.36 & 0.021 \\
Calcium - Ca & 101.34 & 0.000 \\
Magnesium - Mg & 11.89 & 0.000 \\
\hline
\end{tabular}

age in groups, post- hoc tests were used. It was proved that land development, in this case afforestation, of more than $20 \%$, led to a reduction in $\mathrm{TP}, \mathrm{Ca}$ and $\mathrm{Mg}$ content. The afforestation of less than $10 \%$ of the catchment area significantly increases $\mathrm{P}_{-} \mathrm{PO}_{4}{ }^{3-}$ and less than $20 \%$ increases EC, $\mathrm{Ca}^{2+}$ and $\mathrm{Mg}^{2+}$.

\section{Conclusions}

The studied drainage basins considerably differ in terms of water abundance as indicated by runoff rates.

The analysis of variance performed on hydrochemical characteristics of the studied rivers divides the rivers into two separate groups: rivers with a much higher content of phosphorus, calcium and magnesium compounds - Struga Rychnowska, Trynka, Ruziec, Lubianka, Kujawka, Sandela and Gizela (predominance of agricultural areas in the land use structure of the drainage basin); and the group of rivers with low content of these compounds - Brynica, Brodniczanka, Skarlanka, Wel, Iłga (predominance of forests in the drainage basin and flow-through lakes along the river course).

During the studied period, no apparent seasonality in the water runoff from the studied drainage basins or distinct seasonal fluctuations in the concentrations of the studied compounds were observed.

Table 5. Post-hoc comparisons of the impact of forestation on the hydrochemical indicators of river waters

\begin{tabular}{lllllll}
\hline Forestation & $\mathrm{TP}$ & $\mathrm{P}_{-\mathrm{PO}}$ & $\mathrm{EC}$ & $\mathrm{pH}$ & $\mathrm{Ca}$ & $\mathrm{Mg}$ \\
\hline$[\%]$ & {$[\mathrm{Mean} \pm \mathrm{SD}]$} & {$[$ Mean $\pm \mathrm{SD}]$} & {$[$ Mean \pm SD $]$} & {$[$ Mean \pm SD $]$} & {$[$ Mean \pm SD] } & {$[\mathrm{Mean} \pm \mathrm{SD}]$} \\
\hline$<10$ & $0.414 \pm 0.437 a$ & $0.131 \pm 0.152 a$ & $653.8 \pm 92.63 a$ & $7.95 \pm 0.25 a$ & $109.24 \pm 21.14 a$ & $26.26 \pm 8.89 a$ \\
$10-20$ & $0.274 \pm 0.177 a$ & $0.054 \pm 0.025 b$ & $622 \pm 86.79 a$ & $7.92 \pm 0.26 a$ & $110.14 \pm 15.21 a$ & $27.21 \pm 10.25 a$ \\
$20-40$ & $0.108 \pm 0.039 b$ & $0.051 \pm 0.032 b$ & $392 \pm 34.32 b$ & $8.06 \pm 0.29 a$ & $60.87 \pm 6.91 b$ & $18.50 \pm 7.60 b$ \\
$>60$ & $0.104 \pm 0.062 b$ & $0.044 \pm 0.027 b$ & $329 \pm 62.31 c$ & $8.13 \pm 0.24 b$ & $58.06 \pm 12.78 b$ & $15.02 \pm 5.95 b$ \\
\hline
\end{tabular}




\section{References}

Banaszuk P., 2007, Wodna migracja rolniczych zanieczyszczeń obszarowych do wód powierzchniowych w zlewni górnej Narwi (Transport of diffuse agriculture-derived pollutants to surface waters in the upper Narew drainage basin), Wydaw. PB, Białystok, pp. 182 (in Polish).

Behrendt H., Opitz D., 1999, Retention of nutrients in river systems: dependence on specific run off and hydraulic load, Hydrobiologia 410: 111-122.

Bogdanowicz R., 2004, Hydrologiczne uwarunkowania transport wybranych związków azotu I fosforu Odrą I Wisłą oraz rzekami Przymorza do Bałtyku (Hydrological factors influencing transport of selected nitrogen and phosphorus compounds from the Odra River, the Vistula River and Polish coastal rivers to the Baltic Sea), Wydaw. UG, Gdańsk, (in Polish, English summary).

[EC] European Commission, 2000, Directive 2000/60/EC of the European Parliament and of the Council of 23 October 2000 establishing a framework for Community action in the field of water policy, Offic. J. Eur. Union L327: 1-72.

Glińska-Lewczuk K., Burandt P., 2011, Effect of river straightening on the hydrochemical properties of floodplain lakes: Observations from the Łyna and Drwęca Rivers: N. Poland, Ecol. Eng. 37(5): 786-795.

Grant R., Laubel B., Kronvang B., Andersen H.E., Svendsen L.M., Fuglsang A., 1996, Loss of dissolved and particulate phosphorus from arable catchments by subsurface drainage, Water Res. 30(11): 2633-2642.

Harnisz M., Gołaś I., Pietruk M., 2011, Tetracycline-resistant bacteria as indicators of antimicrobial resistance in protected waters - The example of the Drwęca River Nature Reserve (Poland), Ecol. Indicat. 11(2): 663-668.

Haygarth P.M., Jarvis S.C., 1999, Transfer of phosphorus from agricultural soils, Adv. Agron. 66: 195-249.

Heathwaite A.L., Dils R.M., 2000, Characterising phosphorus loss in surface and subsurface hydrological pathways, Sci. Tot. Environ. 251/252: 523-538.

Jasiewicz Cz., Baran A., 2006, Rolnicze źródła zanieczyszczenia wód - biogeny (Agricultural sources of water pollutions - nutrients), J. Elementol. 11(3): 367-378 (in Polish, English summary).

Koc J., Duda M., 2009, The role of storage reservoirs in reducing calcium migration from agricultural catchments, J. Elementol. 14 (3): 467-476.

Koc J., Sobczyńska-Wójcik K., Skwierawski A., 2008, Magnesium concentrations in the waters of re-naturised reservoirs in rural areas, J. Elementol. 13(3): 329-340.
Koc J., Szymczyk S., 2003, Wpływ intensyfikacji rolnictwa na odpływ z gleb fosforu do wód powierzchniowych (The impact of agriculture on the intensity of the outflow of soil phosphorus to surface waters), Zesz. Probl. Post. Nauk Roln. 494: 183-189 (in Polish, English summary).

Kowalkowski T., 2009, Classification of nutrient emission sources in the Vistula River system, Environ. Pollut. 157: 1867-1872.

Mainstone C. P., Parr W., 2002, Phosphorus in river - ecology and management, Sci. Tot. Environ. 282/283: 25-47.

McDowell R.W., Sharpley A.N., Condron L.M., Haygarth P.M., Brookes P.C., 2001, Processes controlling soil phosphorus release to runoff and implications for agricultural management, Nutr. Cycl. Agroecos. 59: 269-284.

McDowell R.W., Biggs B.J.F., Sharpley A.N., Nguyen L., 2004, Connecting phosphorus loss from agricultural landscape to surface water quality, Chem. Ecol. 20: 1-40.

Neal C., Jarvie H.P., 2005, Agriculture, community, river eutrophication and the Water Framework Directive, Hydrol. Process. 19: 1895-1901.

Pionke H.B., Gburek W.J., Schnable R.R., Sharpley A.N., Elwinger G.F., 1999, Seasonal flow, nutrient concentration and loading patterns in stream flow draining an agricultural hill-land watershed. J. Hydrol. 220: 62-73.

Pulikowski K., Kostrzewa S., Paluch J., Szewrański S., 2006, Stężenie i ładunek magnezu oraz wapnia w odciekach drenarskich (Concentration and load of magnesium and calcium in drainage waters), J. Elementol. 11(4): 483-494 (in Polish, English summary).

Sharpley A.N., Gburek W.J., Folmar G., Pionke H.B., 1999, Source of phosphorus exported from an agricultural watershed in Pennsylvania, Agr. Water Manag. 41: 77-89.

Soulsby C., Malcolm R., Helliwell R.C., Ferrier R.C., Jenkins A., 2000, Isotope hydrology of the Alt a'Mharcaidh catchment, Cairngorm Mountains, Scotland: implications for hydrology pathways and water residence time, Hydrol. Process. 14(4): 747-762.

Walling D.E., 2005, Tracing suspended sediments in catchment and river systems, Sci. Tot. Environ. 344: 159-184.

Withers P.J.A., Jarvie H.P., 2009, Delivery and cycling of phosphorus in rivers: A review, Sci. Tot. Environ. 400: 379-395.

Żmuda R., 2006, Funkcjonowanie system transport fluwialnego w małej zlewni zagrożonej erozją wodną gleb (Fluvial transport system functioning in a small catchment threatened by soil water erosion), Zesz. Nauk. AR Wroc. 544, Rozpr.243: 1-165 (in Polish, English summary). 
